NASA/TM-2003-212375

\title{
Regenerative Fuel Cell Test Rig at Glenn Research Center
}

Bei-jiann Chang, Donald W. Johnson, and Christopher P. Garcia QSS Group, Inc., Cleveland, Ohio

Ian J. Jakupca

Analex Corporation, Brook Park, Ohio

Vincent J. Scullin and David J. Bents

Glenn Research Center, Cleveland, Ohio 
Since its founding, NASA has been dedicated to the advancement of aeronautics and space science. The NASA Scientific and Technical Information (STI) Program Office plays a key part in helping NASA maintain this important role.

The NASA STI Program Office is operated by Langley Research Center, the Lead Center for NASA's scientific and technical information. The NASA STI Program Office provides access to the NASA STI Database, the largest collection of aeronautical and space science STI in the world. The Program Office is also NASA's institutional mechanism for disseminating the results of its research and development activities. These results are published by NASA in the NASA STI Report Series, which includes the following report types:

- $\quad$ TECHNICAL PUBLICATION. Reports of completed research or a major significant phase of research that present the results of NASA programs and include extensive data or theoretical analysis. Includes compilations of significant scientific and technical data and information deemed to be of continuing reference value. NASA's counterpart of peerreviewed formal professional papers but has less stringent limitations on manuscript length and extent of graphic presentations.

- TECHNICAL MEMORANDUM. Scientific and technical findings that are preliminary or of specialized interest, e.g., quick release reports, working papers, and bibliographies that contain minimal annotation. Does not contain extensive analysis.

- CONTRACTOR REPORT. Scientific and technical findings by NASA-sponsored contractors and grantees.
- CONFERENCE PUBLICATION. Collected papers from scientific and technical conferences, symposia, seminars, or other meetings sponsored or cosponsored by NASA.

- SPECIAL PUBLICATION. Scientific, technical, or historical information from NASA programs, projects, and missions, often concerned with subjects having substantial public interest.

- TECHNICAL TRANSLATION. Englishlanguage translations of foreign scientific and technical material pertinent to NASA's mission.

Specialized services that complement the STI Program Office's diverse offerings include creating custom thesauri, building customized databases, organizing and publishing research results ... even providing videos.

For more information about the NASA STI Program Office, see the following:

- Access the NASA STI Program Home Page at http://www.sti.nasa.gov

- E-mail your question via the Internet to help@sti.nasa.gov

- Fax your question to the NASA Access Help Desk at 301-621-0134

- Telephone the NASA Access Help Desk at 301-621-0390

- Write to:

NASA Access Help Desk

NASA Center for AeroSpace Information 7121 Standard Drive

Hanover, MD 21076 
NASA/TM-2003-212375

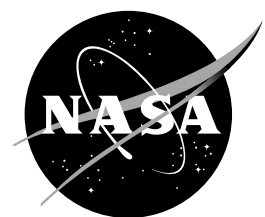

\section{Regenerative Fuel Cell Test Rig at Glenn Research Center}

Bei-jiann Chang, Donald W. Johnson, and Christopher P. Garcia QSS Group, Inc., Cleveland, Ohio

Ian J. Jakupca

Analex Corporation, Brook Park, Ohio

Vincent J. Scullin and David J. Bents

Glenn Research Center, Cleveland, Ohio

Prepared for the

First International Energy Conversion Engineering Conference cosponsored by the American Institute of Aeronautics and Astronautics (AIAA), the American Society of Mechanical Engineers (ASME), and the Institute of Electrical and Electronics Engineers (IEEE)

Portsmouth, Virginia, August 17-21, 2003

National Aeronautics and

Space Administration

Glenn Research Center 
This report is a preprint of a paper intended for presentation at a conference. Because of changes that may be made before formal publication, this preprint is made available with the understanding that it will not be cited or reproduced without the permission of the author.

Available from

NASA Center for Aerospace Information 7121 Standard Drive

Hanover, MD 21076
National Technical Information Service 5285 Port Royal Road Springfield, VA 22100

Available electronically at http:/ /gltrs.grc.nasa.gov 


\title{
REGENERATIVE FUEL CELL TEST RIG AT GLENN RESEARCH CENTER
}

\author{
Bei-jiann Chang, Donald W. Johnson, and Christopher P. Garcia \\ QSS Group, Inc. \\ Cleveland, Ohio 44135 \\ Ian J. Jakupca \\ Analex Corporation \\ Brook Park, Ohio 44142 \\ Vincent J. Scullin ${ }^{*}$ and David J. Bents ${ }^{\dagger}$ \\ National Aeronautics and Space Administration \\ Glenn Research Center \\ Cleveland, Ohio 44135
}

\begin{abstract}
$\underline{\text { ABSTRACT }}$
The regenerative fuel cell development effort at Glenn Research Center (GRC) involves the integration of a dedicated fuel cell and electrolyzer into an energy storage system test rig. The test rig consists of a fuel cell stack, an electrolysis stack, cooling pumps, a water transfer pump, gas recirculation pumps, phase separators, storage tanks for oxygen $\left(\mathrm{O}_{2}\right)$ and hydrogen $\left(\mathrm{H}_{2}\right)$, heat exchangers, isolation valves, pressure regulators, interconnecting tubing, nitrogen purge provisions, and instrumentation for control and monitoring purposes. The regenerative fuel cell (RFC) thus formed is a completely closed system which is capable of autonomous cyclic operation. The test rig provides direct current (DC) load and DC power supply to simulate power consumption and solar power input. In addition, chillers are used as the heat sink to dissipate the waste heat from the electrochemical stack operation. Various vents and nitrogen $\left(\mathrm{N}_{2}\right)$ sources are included in case inert purging is necessary to safe the RFC test rig.
\end{abstract}

\section{NOMENCLATURE}

ASME American Society of Mechanical Engineers

DC Direct Current

ERAST Environmental Research Aircraft and Sensor Technology

GRC Glenn Research Center

IEA Integrated Equipment Assembly

I/O Input/Output

NASA National Aeronautics and Space Administration

\footnotetext{
${ }^{*}$ Scientific Applications Development Branch

${ }^{\dagger}$ Thermo-Mechanical Systems Branch
}

PC Personal Computer

PEM Proton Exchange Membrane

PID Proportional Integral Derivative

RFC Regenerative Fuel Cell

VI Virtual Instrument

\section{INTRODUCTION}

The NASA GRC supports the development of an aerospace hydrogen-oxygen RFC under the Environmental Research Aircraft and Sensor Technology (ERAST) project of the Flight Research Base Program. The ERAST charter includes the development and demonstration of new technologies for unmanned aircraft that are suitable for earth science, including RFC equipped solar electric aircraft with potentially unlimited endurance. Although ERAST is an Aeronautics project, the RFC as a solar energy storage device is applicable to a wide variety of space and planetary surface missions as well as high altitude solar electric flight; hence, the widespread interest throughout NASA to bring this technology to a flight demonstration. Potentially the highest storage capacity and lowest weight of any non-nuclear device, an RFC aboard a solar electric aircraft flown continuously through several successive day-night cycles will provide the most convincing demonstration that this technology's widespread potential has been realized. Leading up to the flight demonstration are several laboratory and full scale demonstrations of key components and subsystems, including the coordinated operation of a hydrogen-oxygen fuel cell and electrolyzer unit as an energy storage system in a sealed, closed loop environment. 


\section{BACKGROUND}

A test stand for evaluating Proton Exchange Membrane (PEM) electrolyzers has been in operation at GRC since January 2000. The stacks tested there include 4-cell, 8-cell short stacks, and full size prototype stacks that consumed $15 \mathrm{kWe}$ power to generate $\mathrm{O}_{2}$ and $\mathrm{H}_{2}$ at pressures up to $400 \mathrm{psig}$. A test stand for characterizing PEM fuel cells was also constructed at GRC, and has been in operation since September 2000. The stacks that were tested on this stand include 4-, 8-, and 10 cell short stacks, and full size prototype stacks that produced up to $5.25 \mathrm{kWe}$ from $\mathrm{O}_{2}$ and $\mathrm{H}_{2}$ reactant gasses at pressures up to $400 \mathrm{psig}$.

Both test stands ran on a once-through basis, i.e., no recycling of $\mathrm{O}_{2}, \mathrm{H}_{2}$, and water. The next step in the GRC test program was to combine the fuel cell and electrolyzer to form a closed loop RFC as an energy storage system based on the experiences gained in operating the two stand-alone test stands. The specific objectives of the RFC test rig were to simulate diurnal charge/discharge cycles, to observe long term performance of RFC, and to identify any degradation mechanisms.

The RFC design ground rules shown in Table 1 were set forth in the beginning of the test rig development. The RFC design specifications were based on solar airplane energy storage requirements and electrochemical stack availabilities. Interface requirements shown in Table 2 defined electrical and fluidic connections between the RFC and the test support equipment. A process block diagram for the regenerative fuel cell test rig was developed as in Figure 1.

TABLE 1.-DESIGN GROUNDRULES FOR REGENERATIVE FUEL CELL TEST RIG

1. Use commercial off-the-shelf and fabricated components to build a working rig initially.

2. Provide flexibility to incorporate flight-like components later.

3. Include additional sensors for data collection.

4. Provide $\mathrm{O}_{2}$ and $\mathrm{H}_{2}$ venting capabilities.

5. Provide $\mathrm{N}_{2}$ purging and vacuum charging as service interfaces, not part of the rig.

6. Provide capability for collecting gas and water grab samples.
TABLE 2.-REGENERATIVE FUEL CELL INTERFACE REQUIREMENTS

Input Power: 0 to15 kW (150A@100.0V)

Output Power: 0 to $5.25 \mathrm{~kW}(100 \mathrm{~A} @ 52.5 \mathrm{~V})$

Maximum Heat Rejection: 4.48 kW (15,290 BTU/HR)

Maximum Inlet Coolant Temperature to Heat Exchanger: $50{ }^{\circ} \mathrm{C}$

Maximum Exit Coolant Temperature from Heat Exchanger: $54{ }^{\circ} \mathrm{C}$

Minimum Inlet Coolant Temperature to 1st Dryer: $0{ }^{\circ} \mathrm{C}$

Maximum Exit Coolant Temperature from 1st Dryer: $5{ }^{\circ} \mathrm{C}$

Minimum Inlet Coolant Temperature to 2nd Dryer: $-40^{\circ} \mathrm{C}$

Maximum Exit Coolant Temperature from 2nd Dryer: $-30{ }^{\circ} \mathrm{C}$

Dimensions: $4 \mathrm{ft} * 6.5 \mathrm{ft} * 8 \mathrm{ft}$ (Excluding $\mathrm{O}_{2}$ and $\mathrm{H}_{2}$ Storage

Tanks)

The following sections describe the mechanical/ electrochemical design, operational concepts, operating modes, control definitions, control/monitor instrumentation, primary control and LabVIEW controller as well as test support equipment.

\section{MECHANICAL/ELECTROCHEMICAL DESIGN}

A mechanical schematic was developed based on the RFC design requirements and specifications. One important design issue had to be resolved before the RFC system design could be finalized; the operating pressure of the fuel cell stack. Because of the difficulties the stack developers experienced in sealing the fuel cell stack at high pressures, pressure regulators were incorporated to allow low-pressure (50-psig) fuel cell operations. A water transfer pump was added to deliver water produced from the fuel cell to the eletrolyzer. Dedicated phase separator tanks were also added. The mechanical schematic reflecting these design decisions was prepared as shown in Figure 2, which details the process block diagram shown in Figure 1 into the following three interconnected process sections: 2(a) Fuel Cell; 2(b) Electrolyzer; 2(c) Reactant Storage Tanks and Driers. The major components list of the RFC is contained in Table 3 that includes the schematic symbol and description of each major component. 


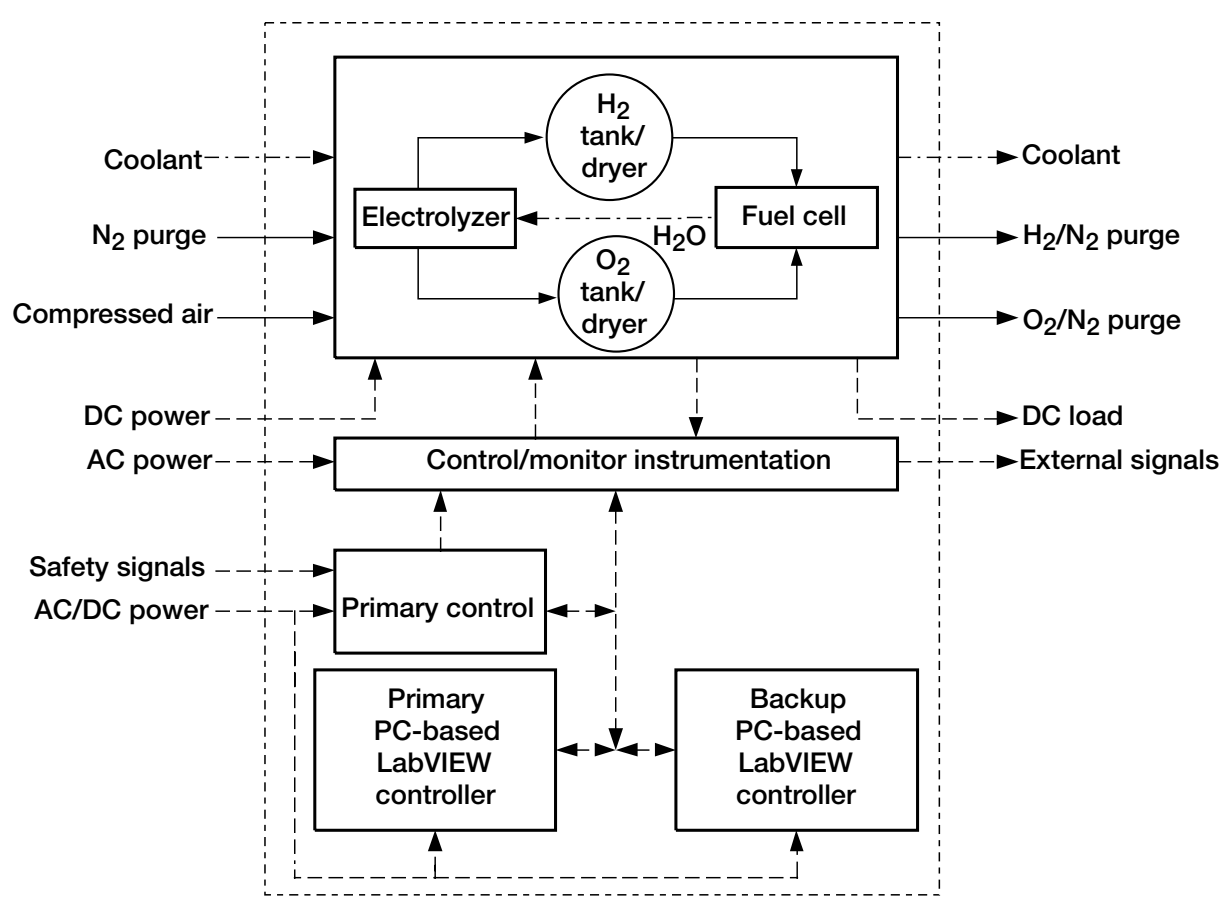

Figure 1.-Regenerative fuel cell test rig process block diagram.

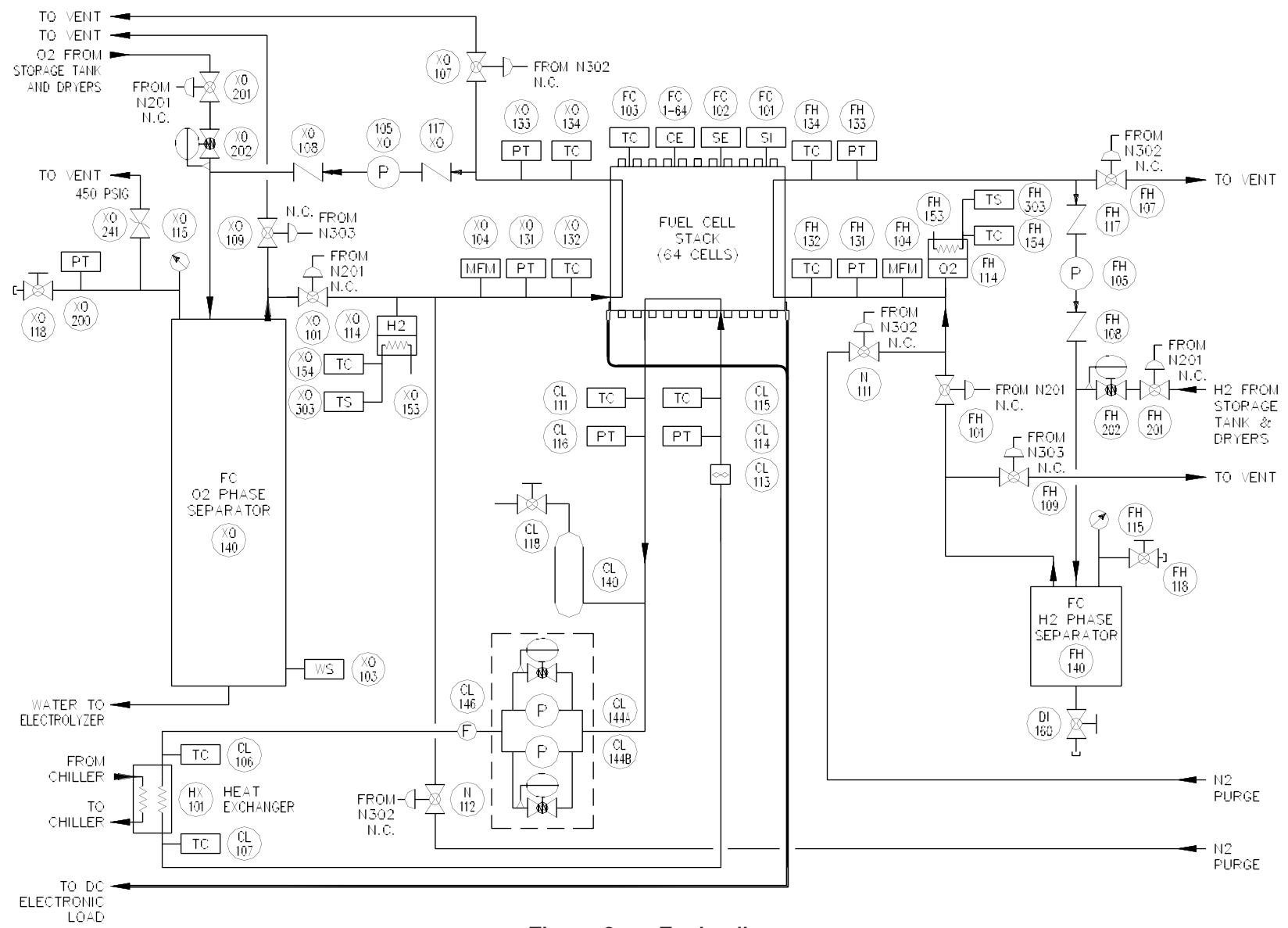

Figure 2a.-Fuel cell. 


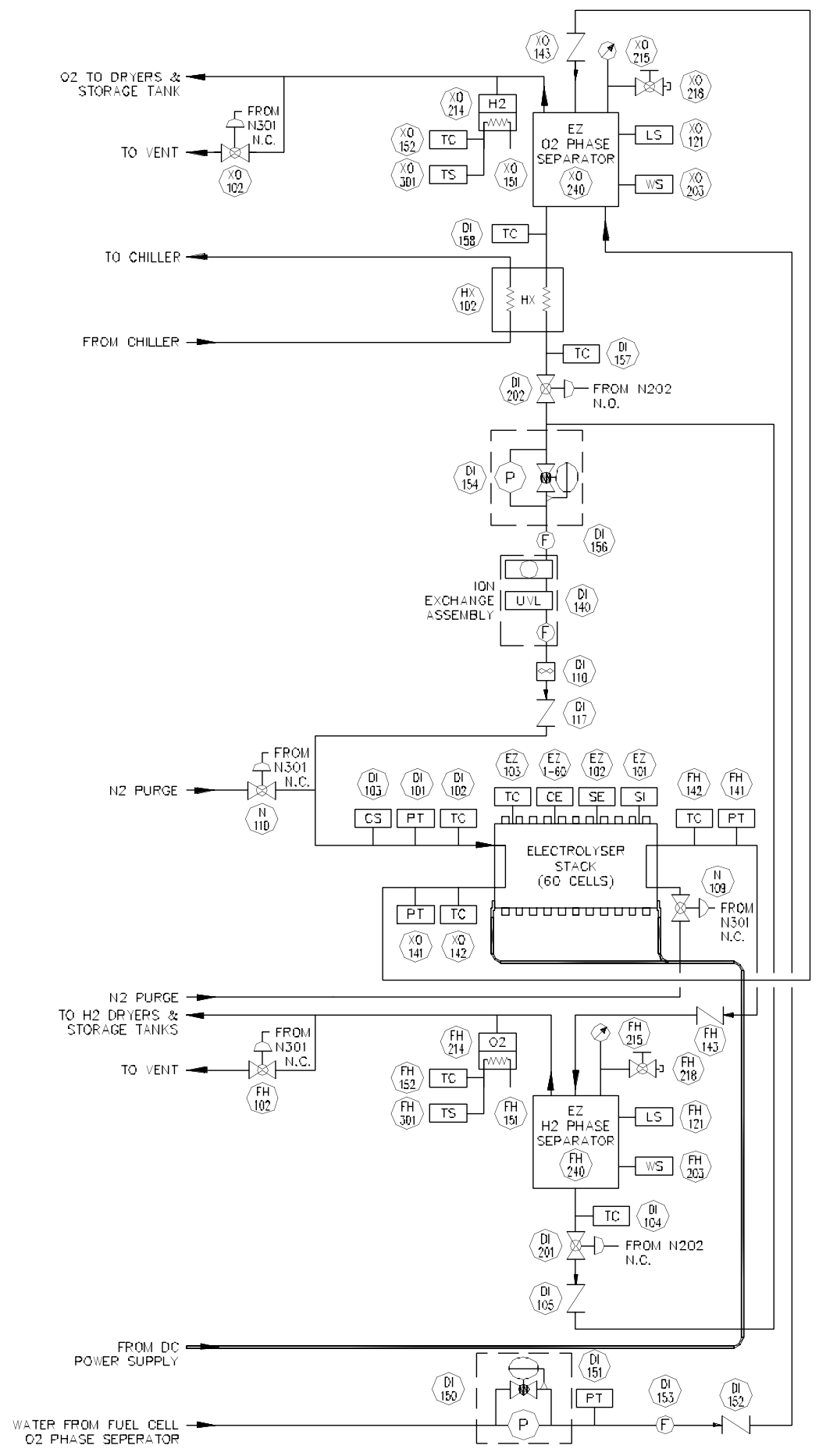

Figure 2b.-Electrolyzer. 


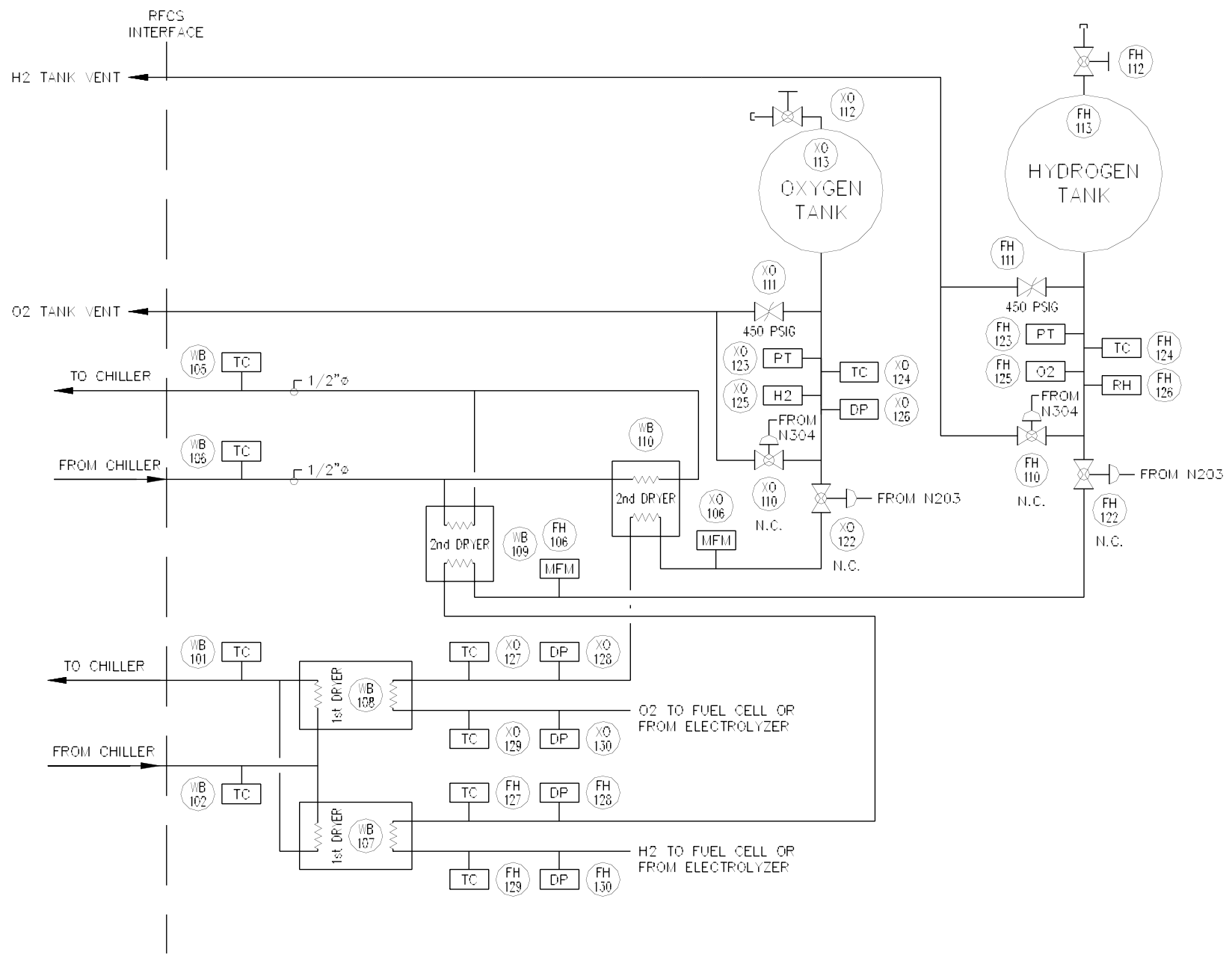

Figure 2c. - Reactant storage tanks and dryers. 
TABLE 3.-RFC COMPONENT LIST

\begin{tabular}{|c|c|}
\hline Schematic Symbol & Description \\
\hline CL 111 & Thermocouple, Type T \\
\hline CL 113 & Flow Meter, Turbine \\
\hline CL 115 & Thermocouple, Type T \\
\hline CL 144 & Pump, Cooling \\
\hline DI 102 & Thermocouple, Type T \\
\hline DI 110 & Flow Meter, Turbine \\
\hline DI 150 & Pump, Transfer \\
\hline DI 154 & Pump, Cooling \\
\hline DI 201 & Valve, Ball, Pneumatic \\
\hline DI 202 & Valve, Ball, Pneumatic \\
\hline EZ 1-60 & Electrolyzer Cell Voltage tabs \\
\hline EZ 101 & Electrolyzer Stack Current shunt \\
\hline EZ 102 & Electrolyzer Stack Voltage \\
\hline FC $1-64$ & Fuel Cell Cell Voltage tabs \\
\hline FC 101 & Fuel Cell Stack Current shunt \\
\hline FC 102 & Fuel Cell Stack Voltage \\
\hline FH 104 & Flow Meter, Laminar \\
\hline FH 105 & Pump, Recirculation \\
\hline FH 113 & Storage Tank, ASME Pressure Vessel \\
\hline FH 114 & Contaminant Sensor \\
\hline FH 139 & Pressure Regulator, Back \\
\hline FH 140 & Phase Separator, Hydrogen \\
\hline FH 201 & Valve, Ball, Pneumatic \\
\hline FH 202 & Pressure Regulator \\
\hline FH 203 & Scale \\
\hline FH 240 & Phase Separator, Hydrogen \\
\hline HX 101 & Heat Exchanger, Shell and Tube \\
\hline HX 102 & Heat Exchanger, Shell and Tube \\
\hline WB 107 & Dryer, First \\
\hline WB 108 & Dryer, First \\
\hline WB 109 & Dryer, Second \\
\hline WB 110 & Dryer, Second \\
\hline $\mathrm{XO} 103$ & Scale \\
\hline XO 104 & Flow Meter, Laminar \\
\hline XO 105 & Pump, Recirculation \\
\hline XO 113 & Storage Tank, ASME Pressure Vessel \\
\hline XO 114 & Contaminant Sensor \\
\hline XO 121 & Sensor, Level \\
\hline XO 139 & Pressure Regulator, Back \\
\hline XO 140 & Phase Separator, Oxygen \\
\hline XO 142 & Thermocouple, Type T \\
\hline XO 201 & Valve, Ball, Pneumatic \\
\hline XO 202 & Pressure Regulator \\
\hline XO 203 & Scale \\
\hline XO 240 & Phase Separator, Oxygen \\
\hline
\end{tabular}

All mechanical/electrochemical components and fluid interconnections are packaged within a frame to form the Integrated Equipment Assembly (IEA), except for

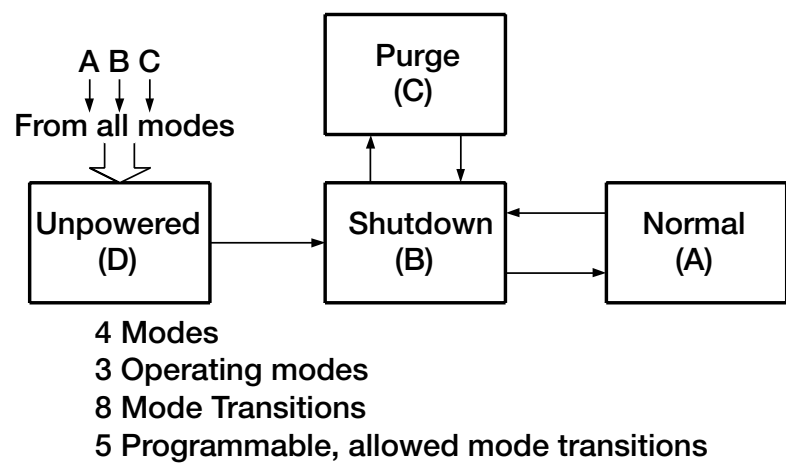

Figure 3.-RFC operating modes and allowable mode transitions.

the gas storage tanks and their associated sensors and valves. The IEA and an instrumentation cabinet are housed inside a shelter. The shelter is in turn located inside a building that serves as the safety barricade during RFC testing when people are not allowed in the test area. The tanks and associated hardware are sited outdoors on opposite sides of the building.

If a fuel cell stack is capable of operating at pressures up to the electrolyzer's maximum pressure, the RFC schematic could be simplified by eliminating the additional cooling pump DI154, water transfer pump DI150, forward pressure regulators XO202 and FH202, as well as phase separators XO240 and FH240. The comparison of the high-pressure with the low- pressure fuel cell stacks in the RFC was discussed previously (Ref. 1). The current test rig may be converted to the "simplified" system at a later time when high-pressure fuel cell stacks become available.

\section{OPERATIONAL CONCEPTS}

During the period of time in which electrical energy is available to be stored, DC electrical power from the energy source (i.e., solar array) is applied to the electrolyzer stack. While the electrolyzer is generating the $\mathrm{O}_{2}$ and $\mathrm{H}_{2}$ product gases, the stack temperature is controlled by the water flow rate with waste heat rejected through heat exchanger HX102. Water consumed on the anode side causes the water level in $\mathrm{O}_{2}$ phase separator $\mathrm{XO} 240$ to decrease and is replenished from the fuel cell $\mathrm{O}_{2}$ phase separator $\mathrm{XO} 140$ via water transfer pump DI150. The water transported to the cathode side by association to migrating protons causes the water level of the $\mathrm{H}_{2}$ phase separator FH240 to rise and is drained periodically by opening valve DI201 and closing valve DI202. Product gases $\mathrm{O}_{2}$ and 
$\mathrm{H}_{2}$ flow through separators $\mathrm{XO} 240$ and $\mathrm{FH} 240$ to drop out bulk liquid water. The gases then pass through 1st dryers WB107 and WB108 to lower the dew point temperature to $40{ }^{\circ} \mathrm{F}$ followed by 2 nd dryers WB109 and WB110 to further lower dew point temperature below $-20^{\circ} \mathrm{F}$. The water condensed in the 1 st dryers is drained back into the phase separators. The water vapor that has changed to ice is stored in the 2nd dryers to be thawed and returned to the fuel cell stack during the next cycle. The dried gases are delivered to reactant storage tanks XO113 and FH113 against rising pressures.

When the electrical energy source is no longer available (i.e., nightfall), or when the reactant storage tank has been filled to its 400 psig pressure limit, the DC power supplied to the electrolyzer is turned off. Valves XO201 and FH201 open to allow reactants $\mathrm{O}_{2}$ and $\mathrm{H}_{2}$ to flow into the fuel cell stack at a stepped down pressure of 50 psig via pressure regulators $\mathrm{XO} 202$ and $\mathrm{FH} 202$. The current draw from the fuel cell will ramp up to the full power of $5.25 \mathrm{kWe}$. Adjusting the pump CL144 motor speed that controls the coolant flow rate through the stack and heat exchanger HX101 maintains the fuel cell stack temperature. The reactants recirculate through the stack using pumps XO105 and FH105. A fixed stoichiometric ratio relative to the current draw is maintained by adjusting the pump speed in response to temperature or pressure changes. The $\mathrm{O}_{2}$ recirculation also ensures the water produced on the cathode side is removed from the stack and stored in the $\mathrm{O}_{2}$ phase separator XO140. The set point of chiller coolant for the 2 nd dryer is raised to $68{ }^{\circ} \mathrm{F}$ to thaw the ice and humidify the reactants to the fuel cell. When sufficient daylight returns or the tank pressure drops below $50 \mathrm{psig}$, the RFC switches back to electrolyzer operation and starts another diurnal cycle.

Water quantities in the system are monitored by weight sensors on the phase separators which allow the operator to track reactant inventory. Contaminant sensors are placed in the $\mathrm{O}_{2}$ and $\mathrm{H}_{2}$ flow streams near the phase separators and storage tanks to detect the presence of combustible mixtures due to gas cross over in the electrochemical stacks. $\mathrm{N}_{2}$ purge is available for the electrolyzer stack plus its phase separators, fuel cell stack, and fuel cell phase separators. The reactant storage tanks can be depressurized if necessary by venting to ambient.

\section{OPERATING MODES}

The RFC operates in one of following four modes: Unpowered, Shutdown, Normal, and Purge. Each mode produces different settings and control states in how the
RFC is operated. Definitions for each of these operating modes is presented in Table 4. Figure 3 illustrates the RFC operating modes and allowable mode transitions. Details of the individual mode transitions are contained in the "RFC Day Cycle Program" control software presented in the "Primary control and LabVIEW Controller" discussion section of this paper.

TABLE 4.-RFC MODE DEFINITIONS

\begin{tabular}{|c|c|}
\hline Mode & Definition \\
\hline Shutdown & 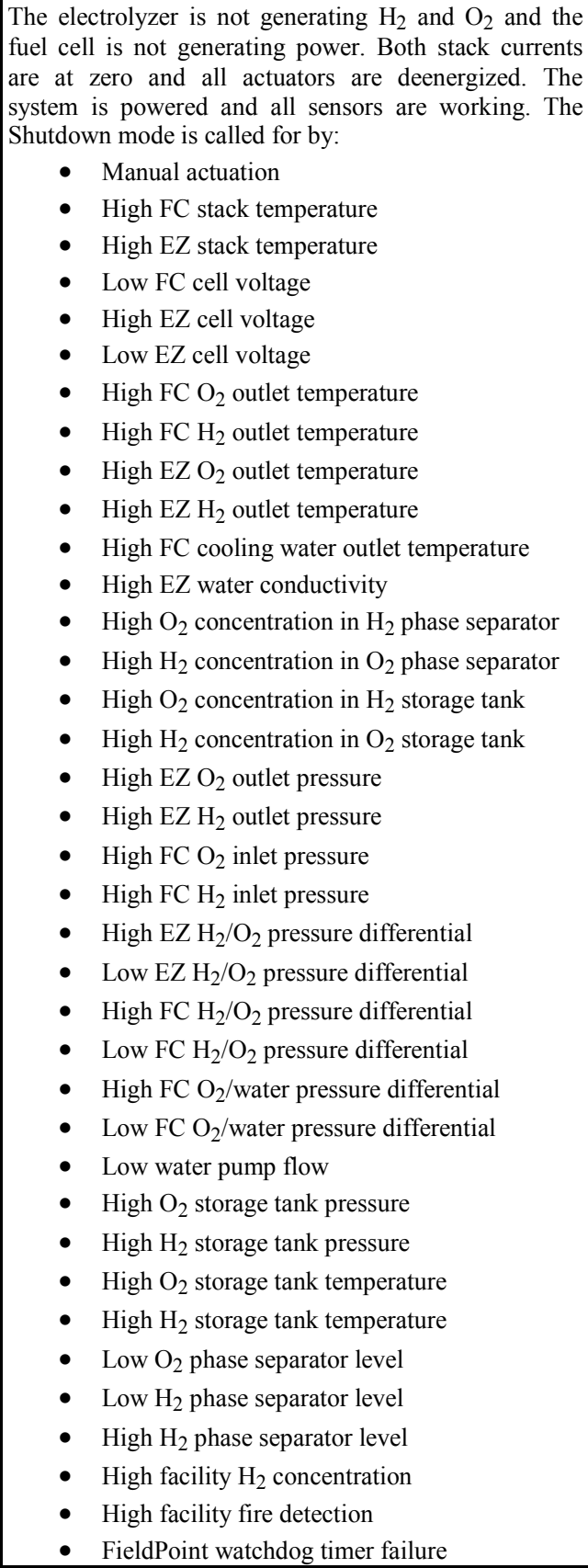 \\
\hline
\end{tabular}


TABLE 4-RFC MODE DEFINITIONS (Concluded)

\begin{tabular}{|c|c|}
\hline Mode & Definition \\
\hline Normal & $\begin{array}{l}\text { The RFC is performing its function, either storing } \mathrm{H}_{2} \\
\text { and } \mathrm{O}_{2} \text { with the electrolyzer operating according to the } \\
\text { power profile or generating electrical power at } \\
5.25 \mathrm{kWe} \text { with the fuel cell. The Normal mode is called } \\
\text { for by: } \\
\text { - Manual actuation }\end{array}$ \\
\hline Purge & $\begin{array}{l}\text { The RFC is being purged with } \mathrm{N}_{2} \text { or vented. There are } \\
\text { four options available: purging electrolyzer stack, } \\
\text { purging fuel cell stack, venting fuel cell phase separator } \\
\text { tanks, or venting storage tanks. The Purge mode is } \\
\text { called for by: } \\
\text { - Manual actuation }\end{array}$ \\
\hline Unpowered & $\begin{array}{l}\text { No electrical power is applied to the RFC. The RFC is } \\
\text { at the pressure and temperature when the power was } \\
\text { lost. The Unpowered mode is called for by: } \\
\text { - Manual actuation (turn switch) } \\
\text { - Electrical power failure }\end{array}$ \\
\hline
\end{tabular}

\section{CONTROL DEFINITIONS}

The process controls for the RFC are listed in Table 5 along with the associated process parameters, actuators, sensors, set points, and ranges. The first six controls are set point changes based on given profiles or conditions. The recirculation flow rate controls and stack temperature controls are feed back controls that require proportional, integral and derivative (PID) control algorithms. Their block diagrams are shown in Figures 4 to 7.

\section{CONTROL/MONITOR INSTRUMENTATION}

National Instruments' FieldPoint ${ }^{\mathrm{TM}}$ input/output (I/O) modules are used to modularize the communication, $\mathrm{I} / \mathrm{O}$ functions, and signal termination of the RFC sensors and actuators. These units are networked using one primary and two backup personal computers (PC's) to perform data acquisition and control functions using Ethernet bus topology. Use of Field Point via an ethernet bus was selected for this test rig due to the need to site the rig in an isolated location and operate it remotely (safety purposes) and the large number of instruments and actuators aboard, which would otherwise need $>750 \mathrm{ft}$ of hard wired connections for each instrument. A fiber optic cable and Ethernet multiport managed switching hubs provide the link between the control room and the shelter location where the rig is sited. Most sensors and actuators in the rig are wired to the FieldPoint distributed modules except for those with RS232 and RS485 serial links that are directly connected to the switching hub at the rig. The data link block diagram is presented in Figure 8.

TABLE 5.-CONTROL DEFINITIONS FOR RFC

\begin{tabular}{|c|c|c|c|c|c|}
\hline No. & Name & Actuator(s) & Sensor(s) & Setpoint(s) & Range(s) \\
\hline 1 & Electrolyzer Current & Power Supply & EZ101 & Variable per Profile & 0 to $150 \mathrm{~A}$ \\
\hline 2 & Fuel Cell Current & Electronic Load & FC101 & $100 \mathrm{~A}$ & 0 to $100 \mathrm{~A}$ \\
\hline 3 & $\mathrm{H}_{2}$ and $\mathrm{O}_{2}$ 2nd Dryer High Temperature & Chiller & $\mathrm{N} / \mathrm{A}$ & $20^{\circ} \mathrm{C}$ & 0 to $25{ }^{\circ} \mathrm{C}$ \\
\hline 4 & $\mathrm{H}_{2}$ and $\mathrm{O}_{2}$ 2nd Dryer Low Temperature & Chiller & N/A & $-40^{\circ} \mathrm{C}$ & -40 to $-30^{\circ} \mathrm{C}$ \\
\hline 5 & EZ $\mathrm{H}_{2}$ Phase Separator Level & $\begin{array}{l}\mathrm{N}_{2} \mathrm{O}_{2} \text { (DI201,DI202) } \\
\text { Energized on high } \\
\text { Deenergized on low }\end{array}$ & FH121 & $\begin{array}{l}\text { High: } 18 \text { in. } \\
\text { Low: } 8 \text { in. }\end{array}$ & 4 to 22 in. \\
\hline 6 & EZ $\mathrm{O}_{2}$ Phase Separator Level & $\begin{array}{l}\text { DI150 } \\
\text { Powered on low } \\
\text { Unpowered on high }\end{array}$ & XO121 & $\begin{array}{l}\text { High: } 18 \text { in. } \\
\text { Low: } 8 \text { in. }\end{array}$ & 4 to $22 \mathrm{in.}$ \\
\hline 7 & $\mathrm{H}_{2}$ Recirculation Flow Rate & FH105 & FH104 & $58 \mathrm{slpm}$ & 0 to 60 slpm \\
\hline 8 & $\mathrm{O}_{2}$ Recirculation Flow Rate & $\mathrm{XO105}$ & XO104 & $45 \mathrm{slpm}$ & 0 to 60 slpm \\
\hline 9 & Electrolyzer Temperature & DI154 & $\begin{array}{l}\text { XO142 } \\
\text { XO142-DI102 }\end{array}$ & $\begin{array}{l}158^{\circ} \mathrm{F} \\
15^{\circ} \mathrm{F}\end{array}$ & $\begin{array}{l}68 \text { to } 178^{\circ} \mathrm{F} \\
0 \text { to } 18^{\circ} \mathrm{F}\end{array}$ \\
\hline 10 & Fuel Cell Temperature & CL144 & $\begin{array}{l}\text { CL111 } \\
\text { CL111-CL115 }\end{array}$ & $\begin{array}{l}158^{\circ} \mathrm{F} \\
15^{\circ} \mathrm{F}\end{array}$ & $\begin{array}{l}68 \text { to } 178^{\circ} \mathrm{F} \\
0 \text { to } 18^{\circ} \mathrm{F}\end{array}$ \\
\hline
\end{tabular}


Facility fire and $\mathrm{H}_{2}$ detectors are placed around the test rig in accordance with the applicable safety standards (Ref. 2). A close circuit television is installed to provide the operator in the control room with audiovisual monitoring of the test rig site.

\section{PRIMARY CONTROL AND LABVIEW CONTROLLER}

The Primary Control relay logic circuit provides manual switching of power to RFC and emergency shutdown capabilities. The facility fire and $\mathrm{H}_{2}$ sensors relay circuit also triggers emergency RFC shutdown if an alarm level is reached. Lights on the panel indicate the system power status. In addition, a reset button is provided to clear a latched emergency shutdown condition. All faults must be resolved to complete a system-reset operation. The block diagram for Primary Control is illustrated in Figure 9.

At the center of the PC-based LabVIEW controller is the RFC Day Cycle Program that consists of a

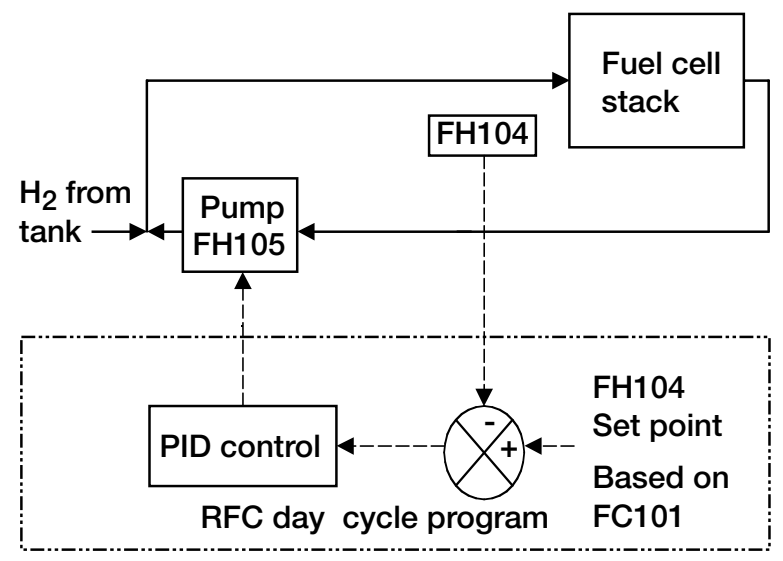

Figure 4. $-\mathrm{H}_{2}$ recirculation flow rate control loop.

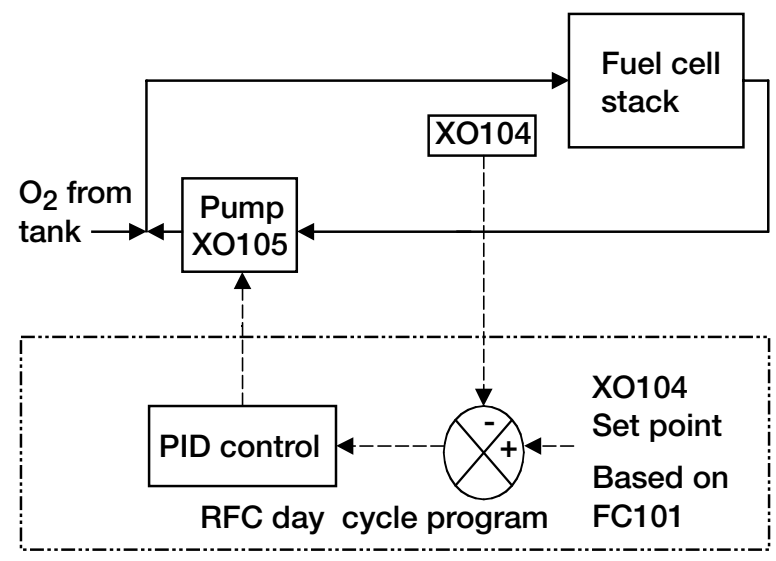

Figure $5 .-\mathrm{O}_{2}$ recirculation flow rate control loop.

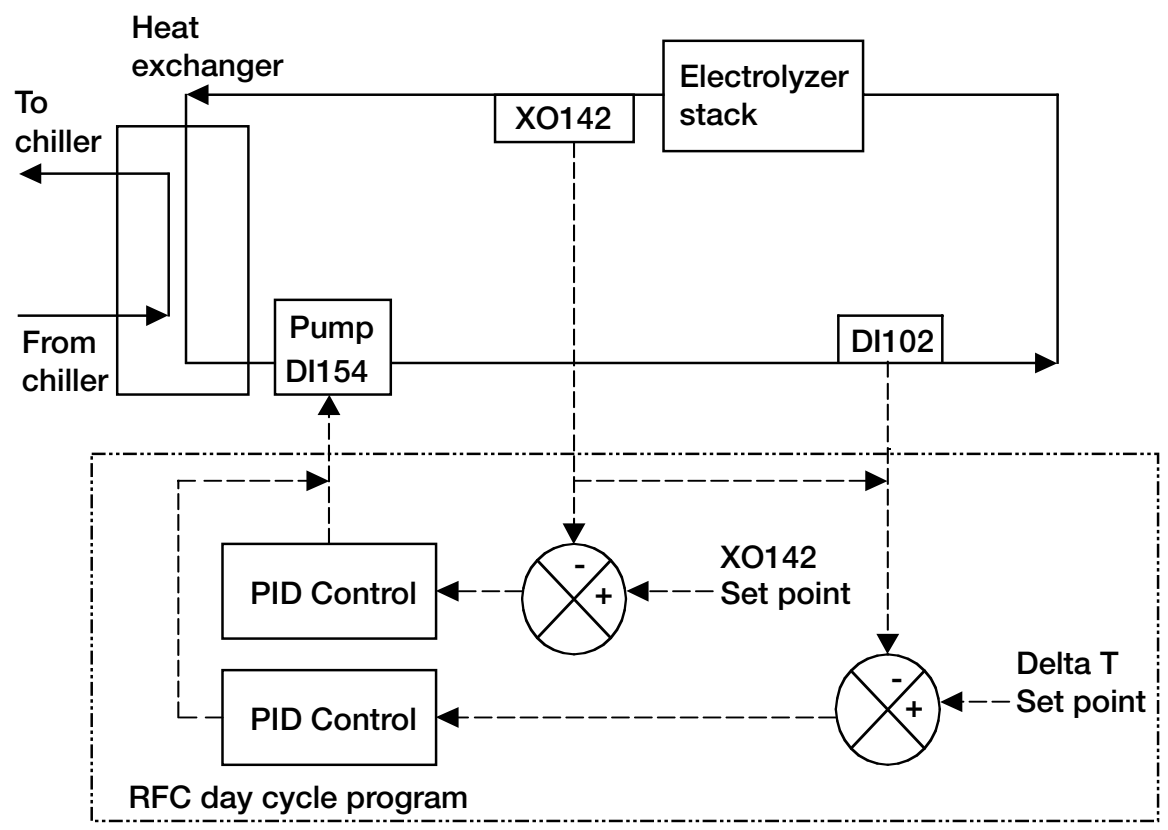

Figure 6.-Electrolyzer temperature control loop. 


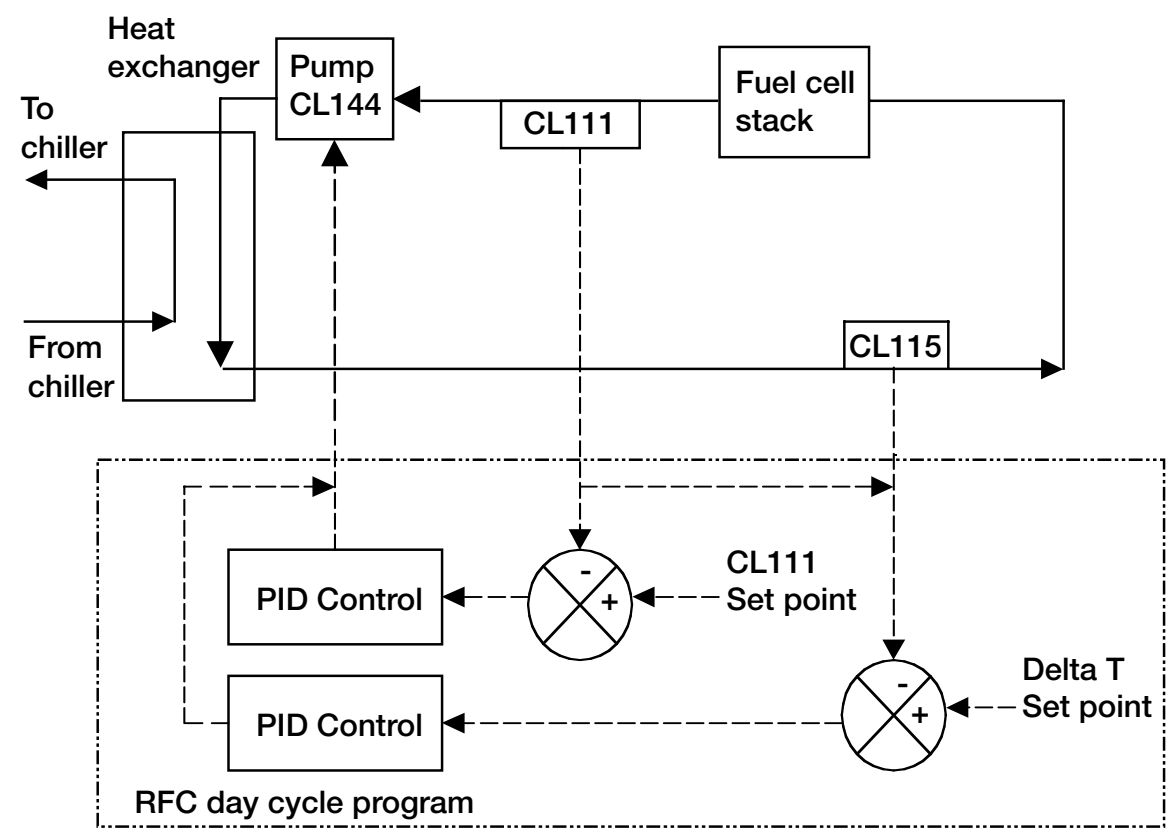

Figure 7.-Fuel cell temperature control loop.

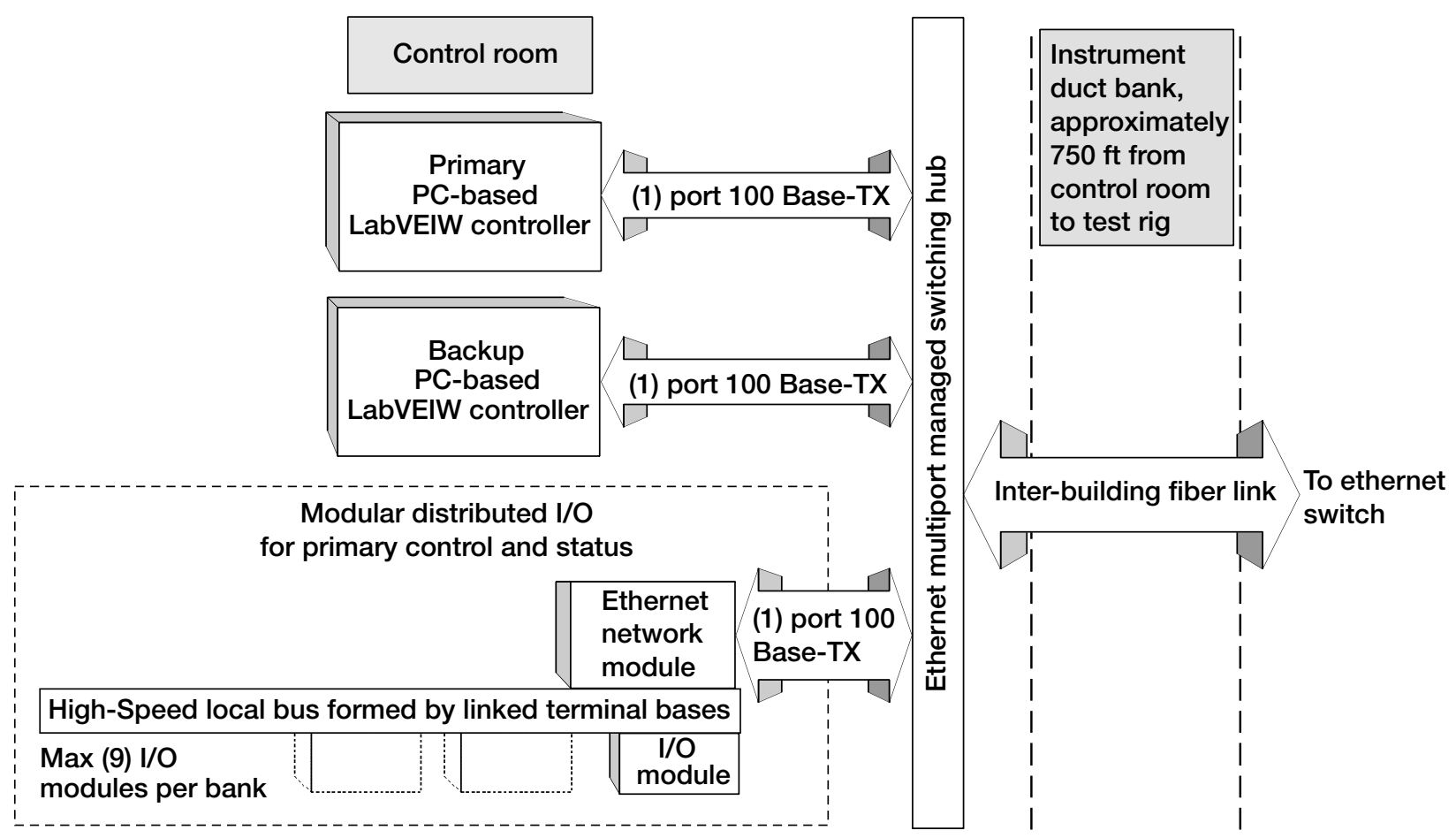

Figure 8a.-Regenerative fuel cell serial data signal topology. 


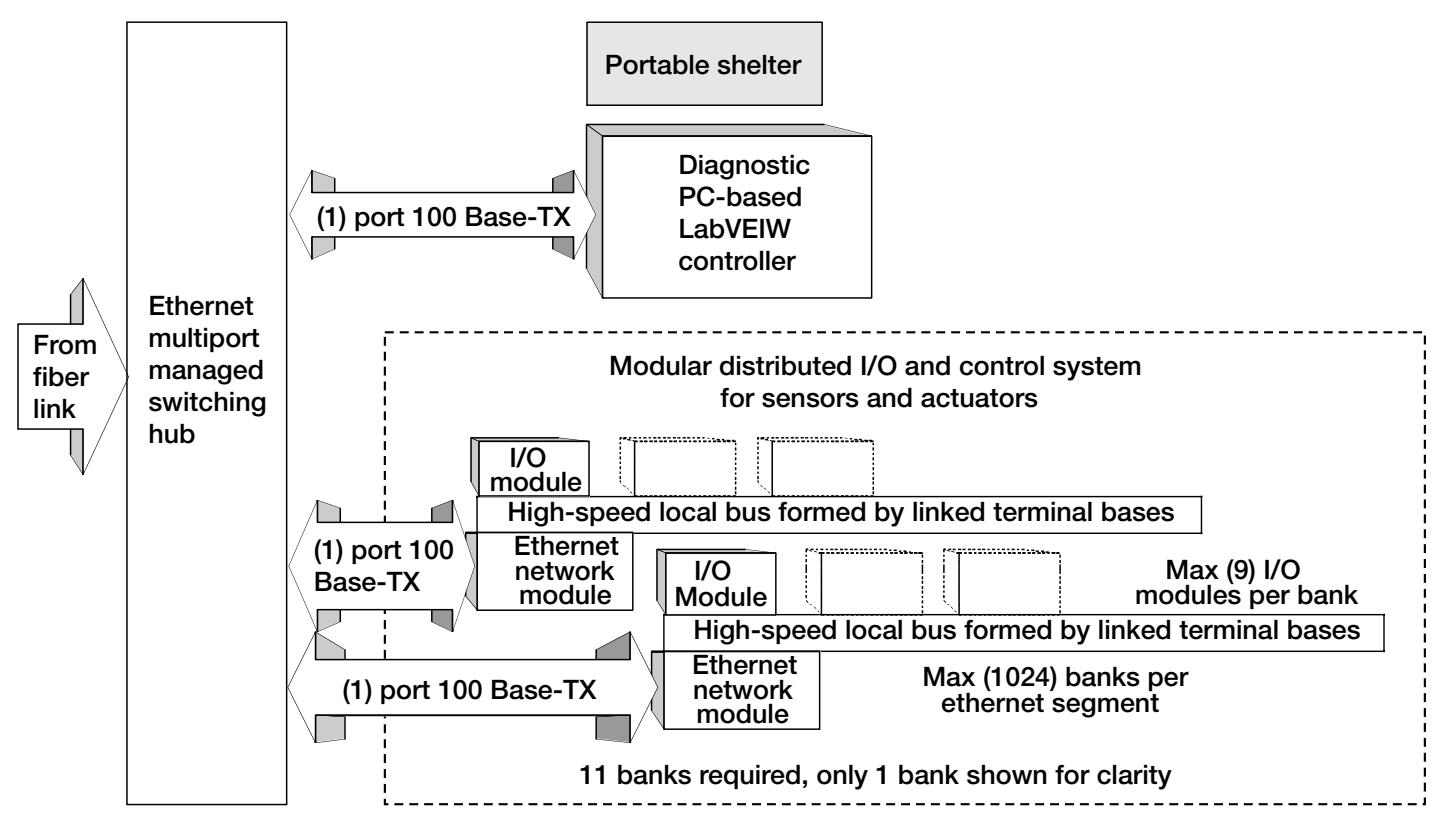

Figure 8b.-Regenerative fuel cell serial data signal topology.

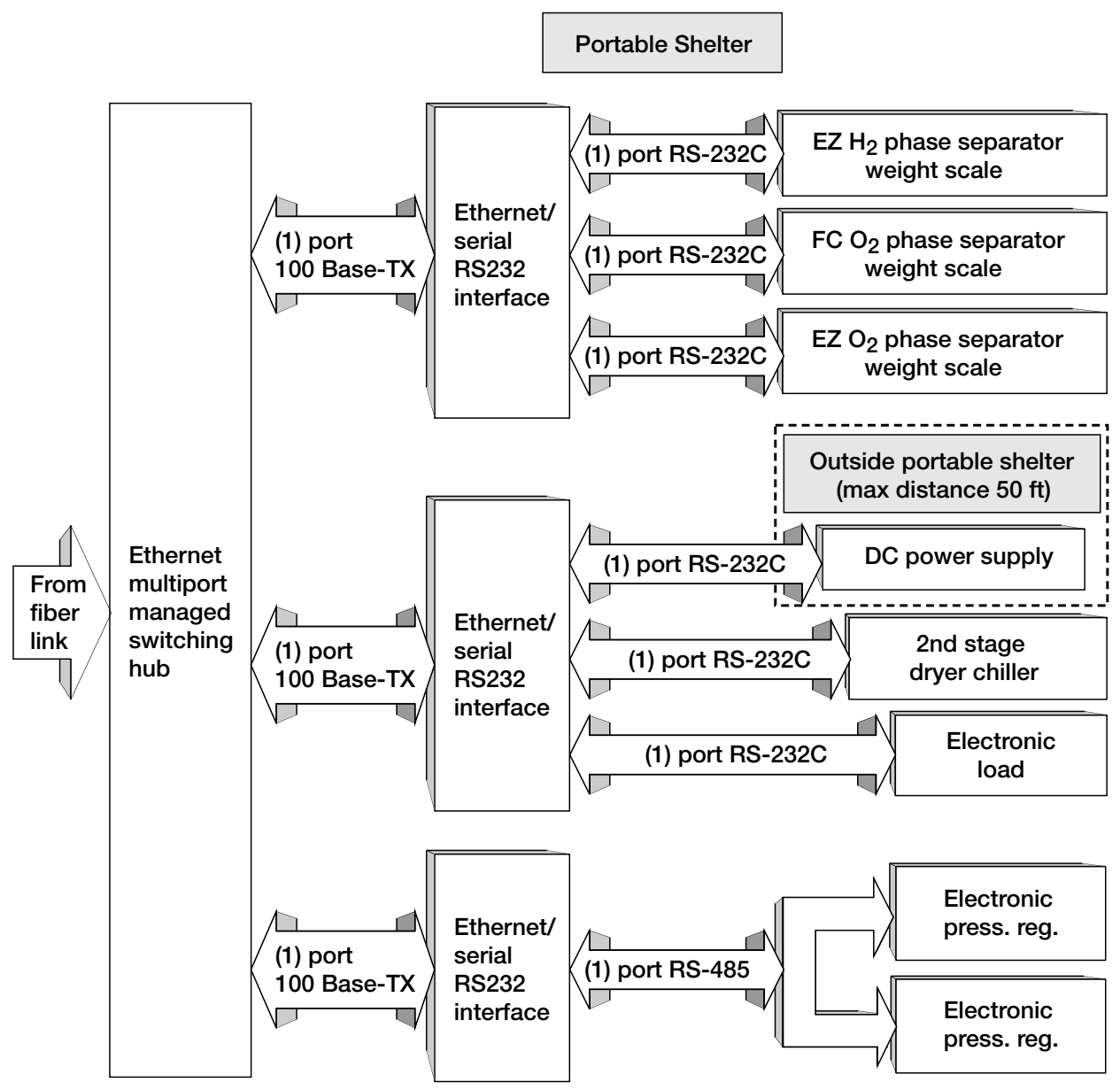

Figure 8c.-Regenerative fuel cell serial data signal topology. 


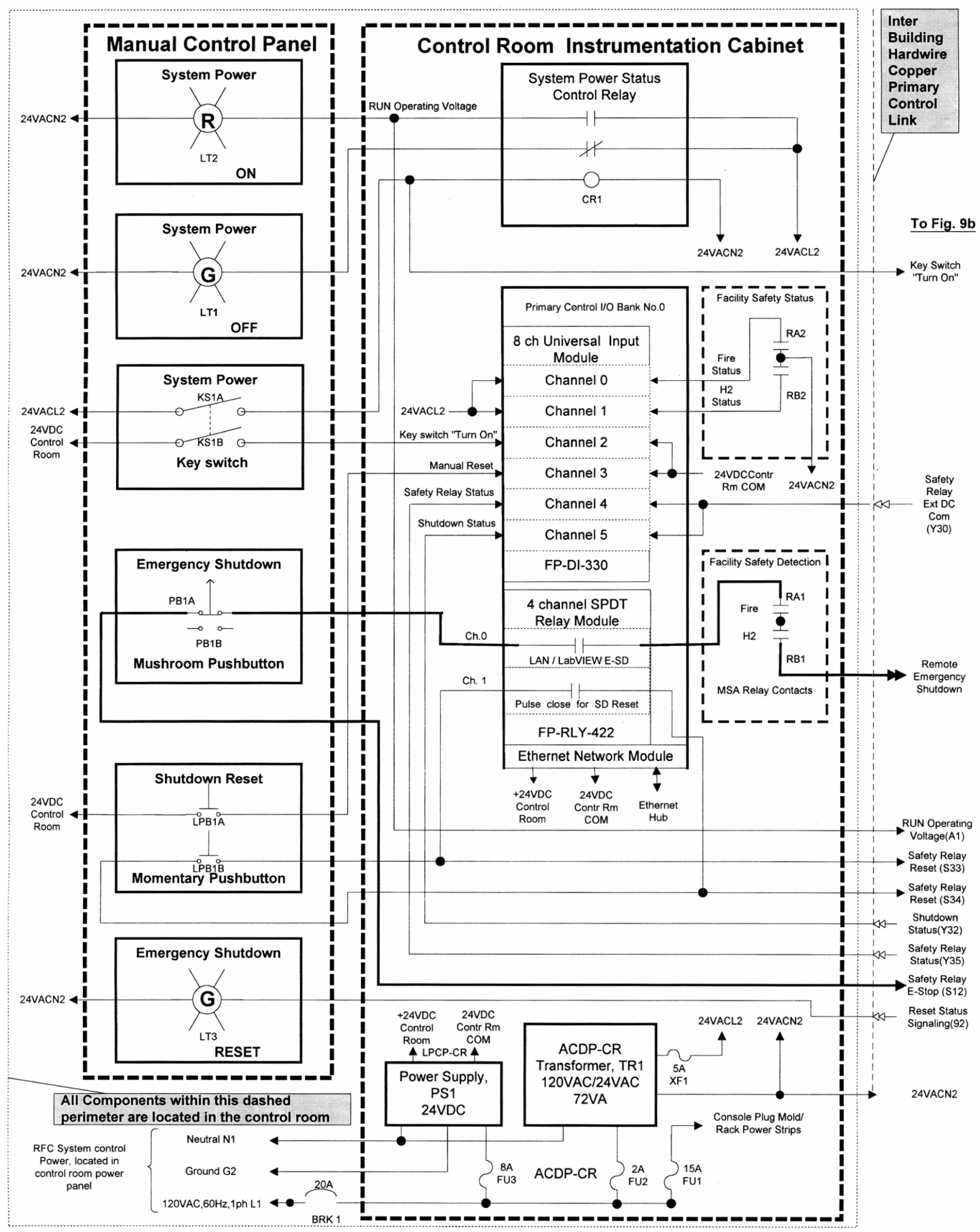

Figure 9a.-Regenerative fuel cell system primary control and facility safety emergency shutdown protection. 


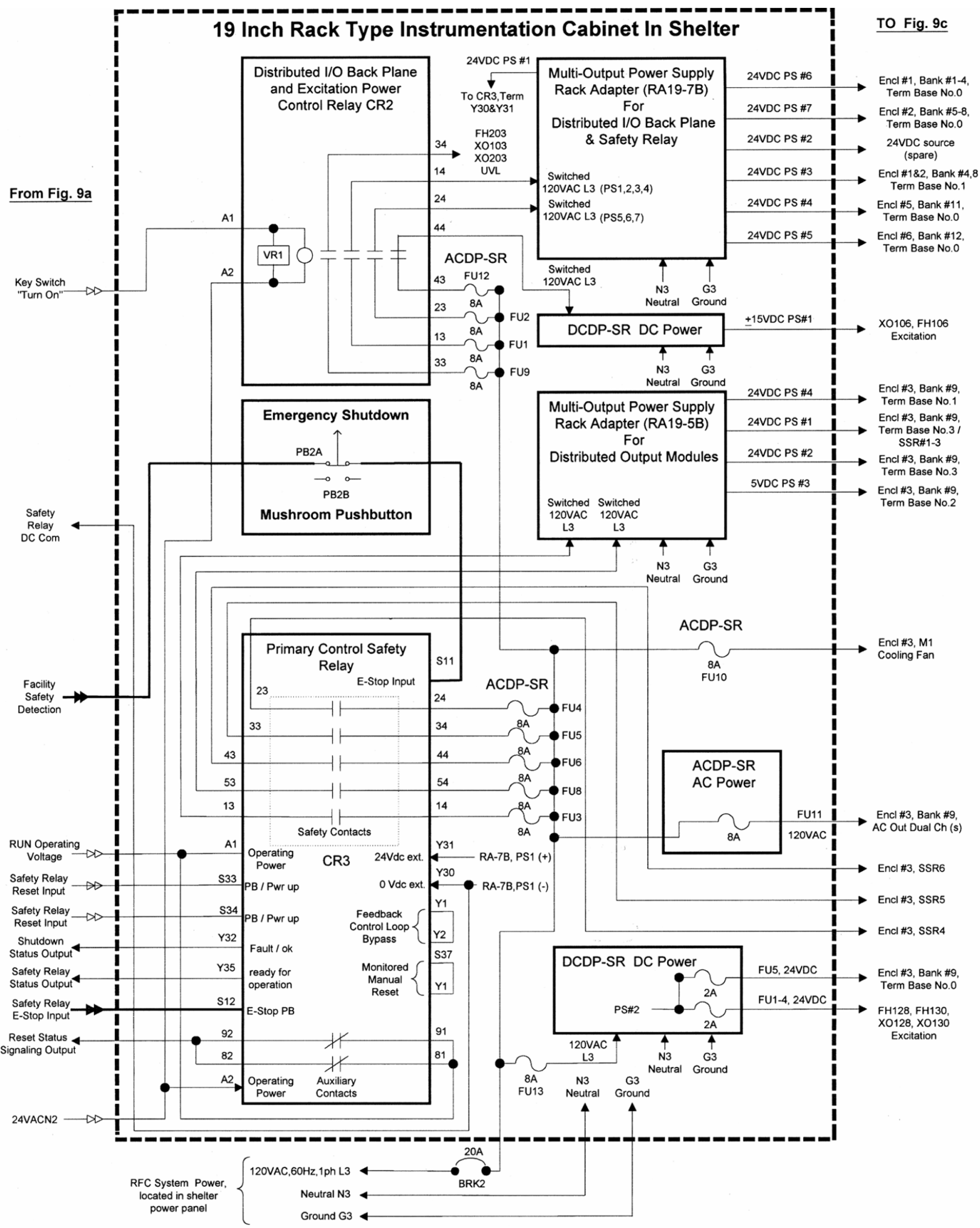

Figure 9b.-Regenerative fuel cell system primary control and facility safety emergency shutdown protection. 


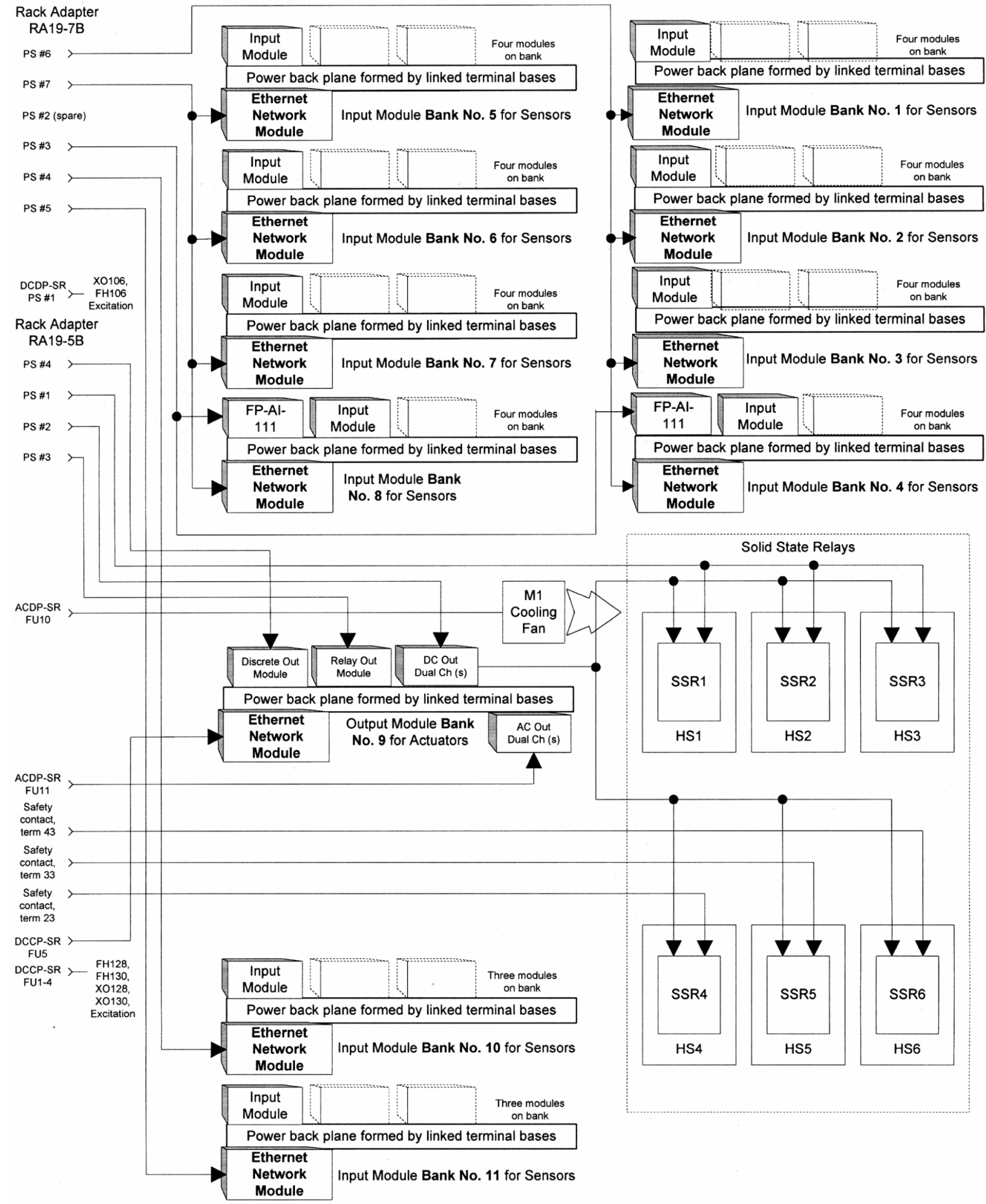

Figure 9c.-Regenerative fuel cell system primary control and facility safety emergency shutdown protection. 
supervisory virtual instrument (VI) and multiple independent VIs called by the supervisory VI. The software program performs the following tasks: sequencing mode transition and cyclic operation, converting and displaying sensor readings in engineering units, running control algorithms, limit checking for warnings and alarms, writing data to files for future retrieval, and providing operator interfaces with the RFC.

The Day Cycle program is designed to run simultaneously on all three of the RFC computers under a master/slave paradigm. As each computer is brought on-line, it listens for a master "heartbeat" from the other PCs. If it does not hear the heartbeat, it starts itself up as the master and begins transmitting the master heartbeat. If it does hear the heartbeat on startup, it designates itself as a slave. The role of the master is to acquire all of the system data and publish that data to the slaves, as well as to operate all of the system controller software. The slave PCs can read the data from the master and display it, and observe, but not direct, all of the controller operations. The slave PCs also listen continuously for the master heartbeat. If that heartbeat should ever disappear, in evidence of a loss of power or functionality on the part of the existing master, then the slave PCs initiate an automatic transfer of authority to make one of them the new master. Which slave becomes the new master depends on: (a) which one first detects the master has dropped out, and (b) where its IP address appears on a predetermined hierarchy list (diagnostic PC comes last). Because the same Day Cycle program runs on all three PCs, any of the three can operate as the master and the RFC system can run with one, two, or all three of the PCs on-line. The primary "master" PC and one "slave" PC reside in the control room. The second "slave" PC resides at the remote site in an instrumentation cabinet next to the equipment, where it is also used for checkout and diagnostic purposes. The front panels of the main screen VI and the process display VI are shown in Figures 10 and 11, respectively.

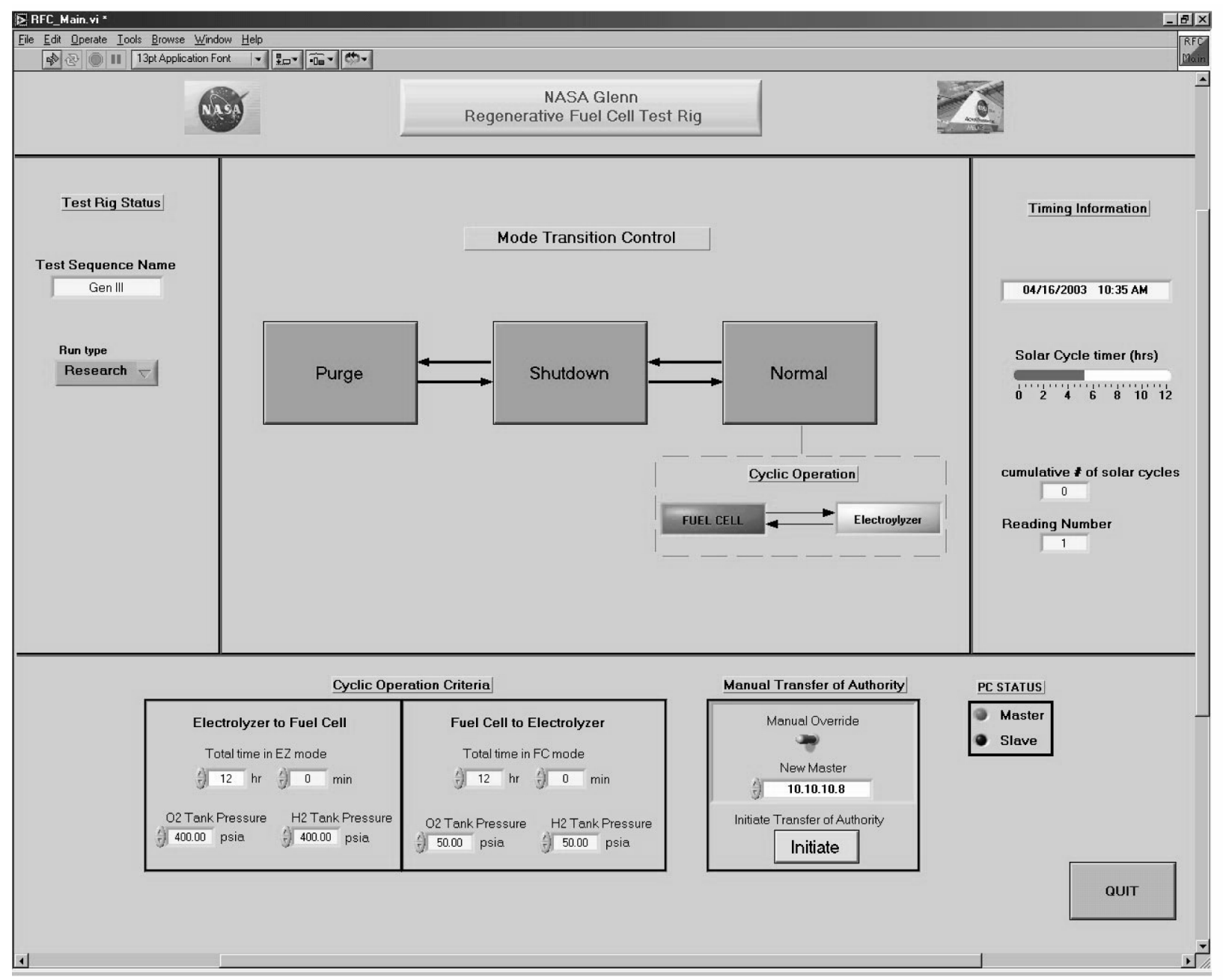

Figure 10.-Main screen VI. 


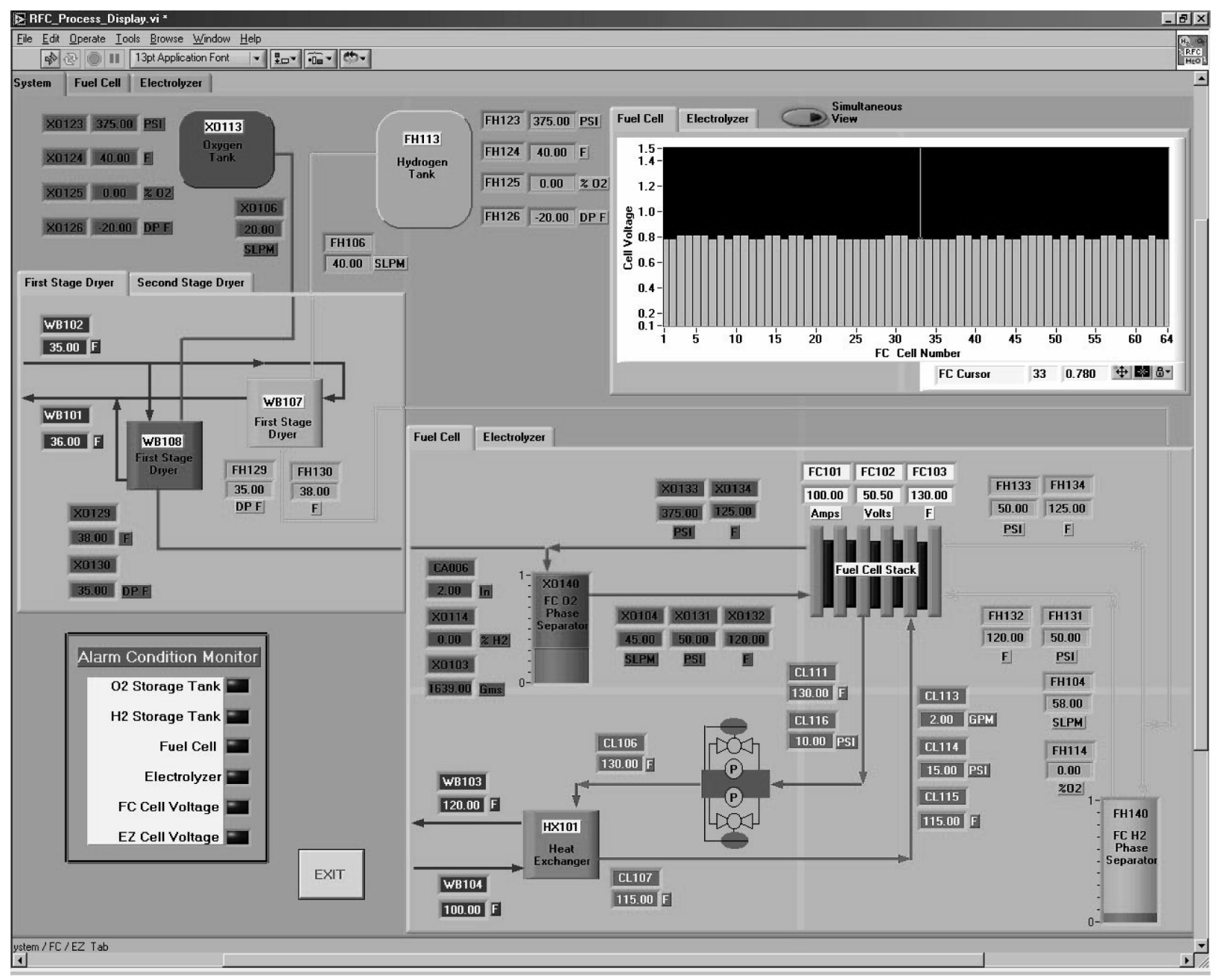

Figure 11._RFC process display VI.

\section{TEST SUPPORT EQUIPMENT}

The test support equipment includes a DC power supply, a DC electronic load, a main chiller, a 1st dryer chiller, a 2nd dryer chiller, a vacuum pump, $\mathrm{N}_{2}$ bottles and compressed air. They are commercially available hardware that provides the interfaces for the RFC testing. Table 6 summarizes the specifications of the test support equipment.
TABLE 6.-TEST SUPPORT EQUIPMENT

\begin{tabular}{|l|l|}
\hline \multicolumn{1}{|c|}{ Item } & \multicolumn{1}{c|}{ Specification } \\
\hline DC Power Supply & 200A @ 150V \\
\hline DC Electronic Load & $12 \mathrm{kWe}$ with 1000A max. \\
\hline Main Chiller & $10 \mathrm{kWe} @ 5 \mathrm{gpm}$ \\
\hline 1st Dryer Chiller & $200 \mathrm{~W} @ 1{ }^{\circ} \mathrm{C}$ \\
\hline 2nd Dryer Chiller & $100 \mathrm{~W} @-40^{\circ} \mathrm{C}$ \\
\hline Vacuum Pump & $<80 \mathrm{mbar}$ \\
\hline $\mathrm{N}_{2} \mathrm{~K}$ bottle & $>450 \mathrm{psig}$ \\
\hline Compressed Air & 80 to $120 \mathrm{psig}$ \\
\hline
\end{tabular}




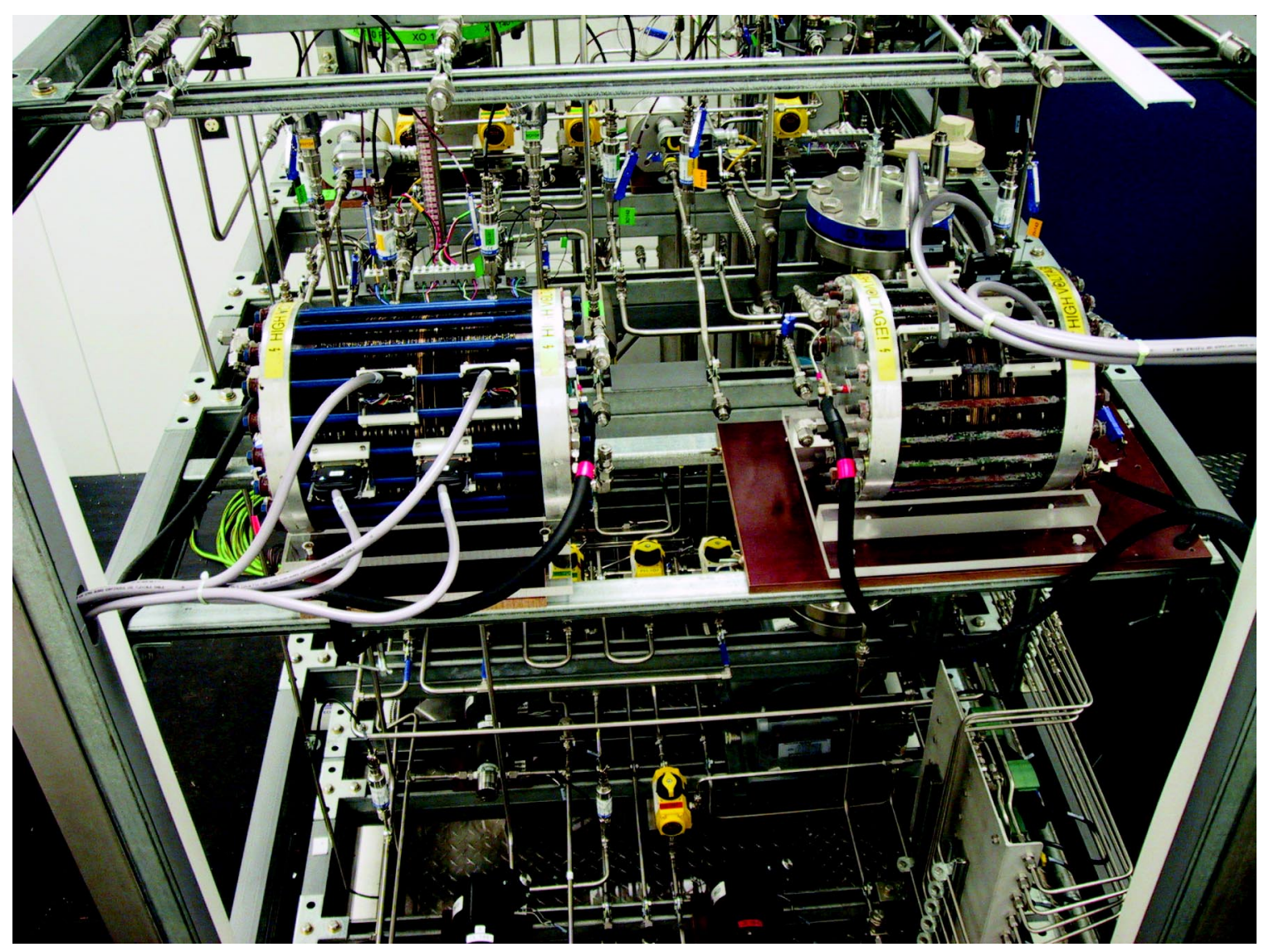

Figure 12.-Integrated equipment assembly.

\section{CONCLUSIONS}

This test rig was built up over calendar year 2002-03 and is presently undergoing mechanical, electrical and software checkout. Figure 12 is a photograph of the IEA with the fuel cell stack and electrolyzer stack shown in the foreground.

Checkout operations of individual process sections per Figures 2(a), 2(b), and 2(c) will commence as soon as the initial checkout is completed. The coordinated operation of fuel cell and electrolyzer subsystems as end-to-end energy storage system is scheduled to take place before the end of fiscal year 2003. Additional characterization tests and inclusion of latest generation of fuel cell and electrolyzer stacks are planned for the future.

\section{REFERENCES}

1. Michael A. Dornheim, "Special Fuel Cells Key to Months-Long Flight," Aviation Week \& Space Technology, February 28, 2000.

2. NASA Glenn Research Center Safety Manual, NHB 1700.1, National Aeronautics and Space Administration, 1997. 


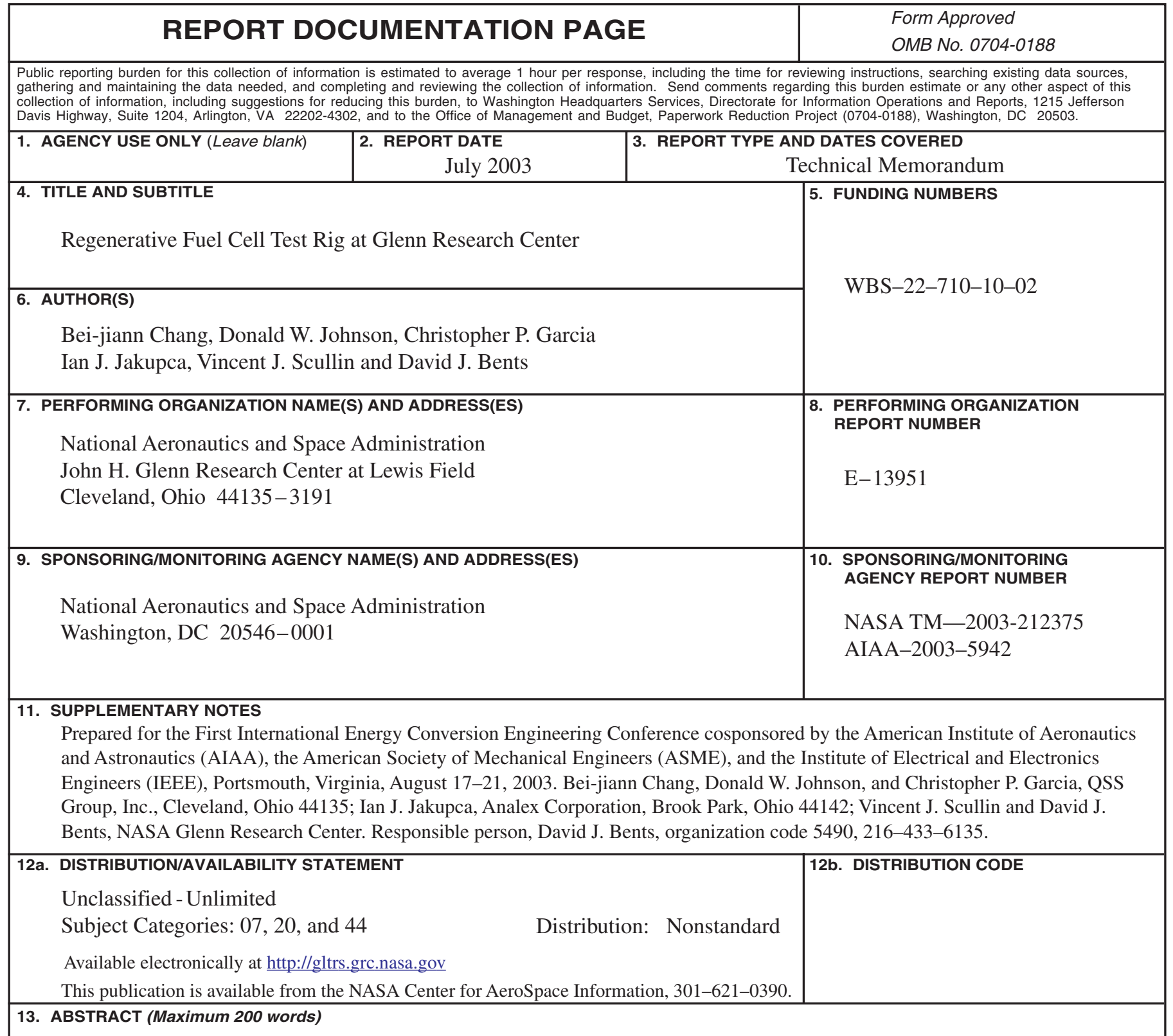

The regenerative fuel cell development effort at Glenn Research Center (GRC) involves the integration of a dedicated fuel cell and electrolyzer into an energy storage system test rig. The test rig consists of a fuel cell stack, an electrolysis stack, cooling pumps, a water transfer pump, gas recirculation pumps, phase separators, storage tanks for oxygen $\left(\mathrm{O}_{2}\right)$ and hydrogen $\left(\mathrm{H}_{2}\right)$, heat exchangers, isolation valves, pressure regulators, interconnecting tubing, nitrogen purge provisions, and instrumentation for control and monitoring purposes. The regenerative fuel cell (RFC) thus formed is a completely closed system which is capable of autonomous cyclic operation. The test rig provides direct current (DC) load and DC power supply to simulate power consumption and solar power input. In addition, chillers are used as the heat sink to dissipate the waste heat from the electrochemical stack operation. Various vents and nitrogen $\left(\mathrm{N}_{2}\right)$ sources are included in case inert purging is necessary to safe the RFC test rig.

\begin{tabular}{|l|l|l|}
\hline $\begin{array}{l}\text { 14. SUBJECT TERMS } \\
\text { Regenerative fuel cells; Energy storage }\end{array}$ \\
\begin{tabular}{|c|c|} 
17. SECURITY CLASSIFICATION \\
OF REPORT \\
Unclassified
\end{tabular} & $\begin{array}{c}\text { 18. SECURITY CLASSIFICATION } \\
\text { OF THIS PAGE } \\
\text { Unclassified }\end{array}$ & $\begin{array}{c}\text { 19. SECURITY CLASSIFICATION } \\
\text { OF ABSTRACT } \\
\text { Unclassified }\end{array}$ \\
\hline
\end{tabular}

